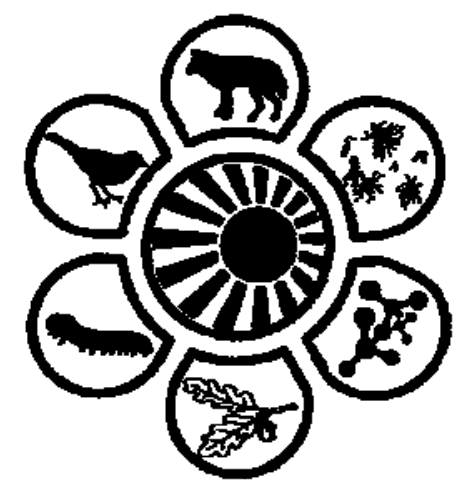

Вісник Дніпропетровського університету. Біологія, екологія.

Vìsnik Dnìpropetrovs'kogo unìversitetu. Seriâ Bìologiâ, ekologiâ

Visnyk of Dnipropetrovsk University. Biology, ecology.

Vìsn. Dnìpropetr. Unìv. Ser. Bìol. Ekol. 2016. 24(1), 230-233.

doi: $10.15421 / 011628$

ISSN 2310-0842 print

ISSN 2312-301X online

www.ecology.dp.ua

UDC 661.162.65:(581.1+582.926.2)

\title{
The use of antigibberelins with different mechanisms of action on morphogenesis and production process regulation in the plant Solanum melongena (Solanaceae)
}

\author{
V.G. Kuriata, V.V. Rohach, T.I. Rohach, T.V. Khranovska \\ Vinnitsa State Pedagogical University named after Mykhailo Kotsyubynskyi, Vinnitsa, Ukraine
}

The influence of antigibberelin on the growth, development and productivity of eggplant was investigated. It was established that the use of tebuconazole and chlormequat chloride is a highly effective tool for regulation of morphogenesis and productivity of eggplant. We found that retardants slowed the growth of plants, and increased the number of leaves and leaf area and dry substance weight of the whole plant. Under the influence of Esfon ethylene producers the inhibition of the growth process was not accompanied by increase of the number, weight and area of leaves. Antigibberelin agents caused the thickening of chlorenchyma and the growth of the columnar cells and cell sizes of spongy parenchyma. Under the action of agents the thickness of the upper and lower epidermis of the leaf increased. As a result of mesostructural and morphometric changes of leaf structure under the influence of retardants the leaf index and specific leaf surface density increased. The growth inhibitory agents increased the chlorophyll content in leaves and caused the growth of chlorophyll index in crops. Retardants reduced the content of sugar and starch in leaves because of their enhanced outflow to fruits, the amount of which was predicted to be greater. Under the influence of Esfon the flow of carbohydrates to the acceptor areas was slower. The use of retardants of triazole and onium origin positively influenced the formation of productivity elements of the culture, which led to increase in the fruit yield. The use of tebuconazole was found to be the most effective.

Keywords: eggplant; morphogenesis; mesostructure; photosynthetic structure; retardants; carbohydrates; productivity

\section{Застосування антигіберелінів із різним механізмом дії для регуляції морфогенезу та продукційного процесу у рослин Solanum melongena (Solanaceae)}

\author{
В.Г. Кур’ята, В.В. Рогач, Т.І. Рогач, Т.В. Храновська
}

Вінницький державний педагогічний університет імені Михайла Кочюбинського, Віннищя, Украӥна

Досліджували вплив антигіберелінових препаратів на ріст, розвиток, листковий апарат, його мезоструктурну організацію та питому поверхвеву щільність листка, ценотичні показники насаджень і продуктивність культури баклажанів. Застосування тебуконазолу та хлормекватхлориду - високоефективний засіб регуляції морфогенезу та продуктивності баклажанів. Препарати гальмували ріст рослин, збільшували кількість і площу листків, масу сирої речовини листків і масу сухої речовини цілої рослини. За дії етиленпродуцента есфону гальмування ростових процесів не супроводжувалося зростанням кількості, маси та площі листків. Препарат також зменшував суху масу всієї рослини порівняно з контролем. Есфон, тебуконазол і хлормекватхлорид зумовлювали потовщення хлоренхіми та зростання об’єму клітин стовпчастої та розмірів клітин губчастої паренхіми. За дії препаратів зростала товщина верхнього та нижнього епідермісу листка. Наслідком мезоструктурних і морфометричних змін листкового апарату за впливу ретардантів тебуконазолу та хлормекватхлориду стало підвищення питомої поверхневої щільності листка та листкового індексу насаджень баклажанів. Усі рістінгібувальні препарати збільшували вміст суми хлорофілів $(\mathrm{a}+\mathrm{b})$ у листках і зумовлювали зростання хлорофільного індексу. Ретарданти тебуконазол і хлормекватхлорид зменшували вміст цукрів і крохмалю в листках внаслідок посиленого їх відтоку до плодів, яких на оброблених препаратами рослинах закладалося більше. За дії есфону відтік вуглеводів до акцепторних зон відбувався повільніше. Застосування триазолпохідного та онієвого ретардантів позитивно вплину-

Вінницький державний педагогічний університет імені Михайла Кочюбинського, вул. Острозького, 32, Вінниия, 21000, Украӥна Vinnitsa State Pedagogical University named after Mykhailo Kotsyubynskiy, Ostrozhskogo Str., 32, Vinnitsa, 21000, Ukraine Тел.: +38-098-594-48-32.E-mail:rogachv@ukr.net 
ло на формування елементів продуктивності культури. За їх впливу відбувалося збільшення кількості плодів на рослині, зросла середня маса одного плоду та підвищувався урожай плодів з однієї рослини. Найефективніше застосування тебуконазолу. За його дії урожайність зросла на 11\%. Обробка хлормекватхлоридом збільшила іiі на 7\%.

Ключові слова: баклажан; мезоструктура; фотосинтетичний апарат; ретарданти; вуглеводи; продуктивність

\section{Introduction}

One of the most important tasks of modern phytophysiology is finding new ways and means of increasing the productivity of crops. The main objective in this regard is to optimize the implementation of the genetic potential of plants while minimizing adverse environmental factors during their ontogeny (Taran et al., 2014; Rogach and Rogach, 2015; Shevchuk and Kur'jata, 2015). More effective and purposeful management of plant productivity may be enabled by synthetic growth and development regulators, among them a prominent place is occupied by antigibberellin agents, retardants (Golunova, 2015; Tkachuk, 2015). It is known that the regulation of the donor-acceptor relations in the system of the whole plant is carried out through photosynthesis and growth function, and any natural or experimental change in the speed of growth processes accompanied by the restructuring of the photosynthetic apparatus. The use of growth regulators of inhibitory type allow the growth of certain plant organs to be delayed, which can result in possible redistribution of flows of assimilates to economically important tissues and organs (Kirizij et al., 2014; Poproc'ka, 2014).

The literature provides information on the use of antigibberellin drugs to optimize the production process for legumes (Golunova and Kur'jata, 2012), essential oils (Polyvanyj and Kur'jata, 2014), berry fruit (Moreira et al., 2011), vegetables (Tkachuk, 2015), decorative plants (de Campos, 2010) and industrial crops (Guljajeva and Kur'jata, 2013; Shevchuk and Kur'jata, 2015). However, the scientific literature does not contain data on the influence of antigibberellin growth regulators on morphogenesis and the productivity process in the eggplant. In this context, the aim of our investigation was to examine the influence of retardants with different mechanisms of action on growth, development and productivity of eggplants of the Almaz sort.

\section{Materials and methods}

Field experiments were carried out on the land of "Berzhan PG" Horbanivka village, Vinnytsia region, in 2013-2015 during the growing season. Aubergine seeds were sown in greenhouses on 03/03/2013, 05/03/2014 and $03 / 09 / 2015$. The seedlings were planted on $05 / 22 / 2013$, $29 / 05 / 2014$ and $12 / 05 / 2015$ by the belt method accotrding to the formula $80+50+50 \times 25$. The fertilizer $\mathrm{N}_{50} \mathrm{R}_{40} \mathrm{~K}_{30}$ was added. The land area was $33 \mathrm{~m}^{2}$ fivefold repetition. The plants were treated in the morning using backpack sprayers OP-2 to complete wetting of leaves with $0.25 \%$ solution chlormequat chloride (CCC-750), 0.025\% solution tebuconazole (EW-250) and $0.15 \%$ solution 2-chloroethylphosphonic acid (2-CEPA) in the budding 17/07/2013, $10 / 07 / 2014$ and $19 / 07 / 2015$. Control plants were sprayed with tap water.

Phytometric indicators (plant height, dry weight and raw material of plants, leaves, leaf area) were determined for 20 plants (Bala et al., 2013). Sampling of materials for the study of leaf mesostructure was conducted in the early phase of bulb growth. Mesostructure of leaf of the research plants was studied on fixed material. For its preservation a mixture of equal parts of ethyl alcohol, glycerine, water with $1 \%$ formalin was used. Determination of cell chlorenchyma and its thickness was performed with a microscope Mykmed-1 ocular micrometer MOV-1-15h. For analysis of mesostructure leaves were taken from the middle tiers (Bala et al., 2013). Determination of chlorophyll expended in fresh material was performed by the spectrophotometric method on a spectrophotometer SF-18 (Bala et al., 2013). During the growing season we determined the net productivity of photosynthesis, leaf surface index and chlorophyll index, specific leaf surface density, yield and yield structure (Bala et al., 2013). The content of the various forms of carbohydrates were determined by the Pochynok test. The yield was determined by counting and weighing from each site separately. The research results were treated statistically using the computer program Statistica 6.0. Single factor analysis of variance was used (difference between the mean values was calculated by Student's test, they were considered significant at $\mathrm{P}<0.05$ ) (Van Emden, 2008). The table shows the mean value and their standard errors.

\section{Results and discussion}

It was found out that antigibberelin drugs such as tebuconazole and chlormequat chloride prompted widespread changes in morphogenesis and performance of eggplants of the cultivar Diamond. We specifically studied the use of retardants tebuconazole, chlormequat chloride, which resulted in reduction of linear dimensions of plants at the end of the growing season by an average of $14-15 \%$ in the years of research (Golunova and Kur'jata, 2012; Shevchuk and Kur'jata, 2015; Tkachuk, 2015). Inhibition of plant growth was more intense when Esfon was used (Table 1).

Reduction in the height of the plants of eggplant under the influence of antigibberellin was accompanied by changes in the structure, size and functioning of vegetative and generative organs. Our studies found changes in the leaf apparatus. We found that processing the plants by Esfon caused a decrease in the number of leaves per plant (Golunova and Kur'jata, 2012; Kur'jata and Polyvanyj, 2015; Shevchuk and Kur'jata, 2015; Tkachuk, 2015).

Leaf area is one of the main morphometric parameters that significantly affect the performance of crops. Investigations have shown that treatment by Esfon reduced the leaf surface area, tebuconazole increased it and for the actions of the onium retardants chlormequat chloride the figure only tended to increase (Golunova, 2015; Kur'jata and Polyvanyj, 2015; Tkachuk, 2015). An important indicator of plantations is the cyanotic index of leaf surface. The leaf index increased during processing by tebuconazole, and with the application of Esfon it decreased, while chlormequat chloride did not significantly change it. 
Morphological characteristic of plants of eggplant of the cultivar Diamond for actions of retardants (fruit formation phase, the average data for 2013-2015, $\mathrm{n}=\mathbf{2 0}$ )

\begin{tabular}{|l|c|c|c|c|}
\hline \multicolumn{1}{|c|}{ Variant of experiment } & Control & 2-CEPA & EW-250 & CCC-750 \\
\hline Plant height, $\mathrm{cm}$ & $54.6 \pm 2.68$ & $39.7 \pm 1.89^{*}$ & $46.4 \pm 2.21^{*}$ & $47.1 \pm 2.28^{*}$ \\
\hline Number of leaves on a plant, units & $88.7 \pm 4.12$ & $70.1 \pm 3.42^{*}$ & $103.1 \pm 5.0^{*}$ & $95.2 \pm 4.71$ \\
\hline The mass of raw leaf material, $\mathrm{g}$ & $141 \pm 6.9$ & $92 \pm 4.5$ & $186 \pm 9.1$ & $179 \pm 8.0$ \\
\hline Leaf area, $\mathrm{cm}^{2}$ & $6179 \pm 302$ & $3298 \pm 160^{*}$ & $7526 \pm 367^{*}$ & $6989 \pm 332$ \\
\hline Leaf index, $\mathrm{m}^{2} / \mathrm{m}^{2}$ & $4.12 \pm 0.181$ & $2.20 \pm 0.094^{*}$ & $5.01 \pm 0.232^{*}$ & $4.66 \pm 0.211$ \\
\hline Specific leaf surface density, $\mathrm{mg} / \mathrm{cm}^{2}$ & $5.30 \pm 0.222$ & $6.17 \pm 0.283^{*}$ & $6.02 \pm 0.255^{*}$ & $6.13 \pm 0.276^{*}$ \\
\hline Volume column parenchyma cells, mkm ${ }^{3}$ & $3989 \pm 246$ & $5671 \pm 233^{*}$ & $7657 \pm 412^{*}$ & $6300 \pm 298^{*}$ \\
\hline Length spongy parenchyma cells, $\mu \mathrm{m}$ & $18.8 \pm 0.89$ & $27.1 \pm 1.17^{*}$ & $26.8 \pm 0.83^{*}$ & $27.3 \pm 1.08^{*}$ \\
\hline The width of the spongy parenchyma cells, $\mu \mathrm{m}$ & $9.6 \pm 0.48$ & $17.0 \pm 0.71^{*}$ & $18.4 \pm 0.77^{*}$ & $17.5 \pm 0.66^{*}$ \\
\hline The thickness of the upper epidermis, $\mu \mathrm{m}$ & $20.6 \pm 0.91$ & $21.2 \pm 0.38$ & $23.1 \pm 0.51^{*}$ & $25.0 \pm 0.78^{*}$ \\
\hline Chlorenchyma thickness, mm & $155 \pm 3.2$ & $160 \pm 3.5$ & $169 \pm 2.3^{*}$ & $162 \pm 3.8$ \\
\hline The thickness of the lower epidermis, $\mu \mathrm{m}$ & $16.0 \pm 0.65$ & $21.0 \pm 0.33^{*}$ & $20.8 \pm 0.48^{*}$ & $22.9 \pm 1.13^{*}$ \\
\hline The content of chlorophyll sum $(\mathrm{a}+\mathrm{b}), \%$ & $0.495 \pm 0.023$ & $0.524 \pm 0.026$ & $0.576 \pm 0.028^{*}$ & $0.548 \pm 0.027$ \\
\hline Chlorophyll index, g/m ${ }^{2}$ & $1.13 \pm 0.051$ & $1.46 \pm 0.067^{*}$ & $1.42 \pm 0.065^{*}$ & $1.40 \pm 0.063^{*}$ \\
\hline Weight of plant dry matter, $\mathrm{g}$ & $109 \pm 4.8$ & $82 \pm 3.9^{*}$ & $143 \pm 7.0^{*}$ & $140 \pm 6.4^{*}$ \\
\hline The net productivity of photosynthesis, $\mathrm{g} / \mathrm{m}^{2} \cdot \mathrm{day}$ & $10.1 \pm 0.48$ & $14.9 \pm 0.69^{*}$ & $11.0 \pm 0.50$ & $10.4 \pm 0.47$ \\
\hline The weight of dry matter of fruit, $\mathrm{g}$ & $42.6 \pm 1.96$ & $31.5 \pm 1.51^{*}$ & $56.9 \pm 2.69^{*}$ & $62.5 \pm 3.03^{*}$ \\
\hline Number of fruit per plant, units & $4.04 \pm 0.183$ & $3.58 \pm 0.121^{*}$ & $4.66 \pm 0.190^{*}$ & $4.27 \pm 0.175$ \\
\hline The average weight of a fetus, $\mathrm{g}$ & $136 \pm 3.1$ & $142 \pm 3.8$ & $150 \pm 4.2^{*}$ & $145 \pm 4.0$ \\
\hline Weight of the fruit from one plant, $\mathrm{g}$ & $552 \pm 26.9$ & $520 \pm 24.4$ & $707 \pm 32.0^{*}$ & $620 \pm 30.0$ \\
\hline The yield fruit, tha & $36.4 \pm 1.06$ & $34.3 \pm 1.33$ & $46.6 \pm 1.22^{*}$ & $40.9 \pm 1.21^{*}$ \\
\hline
\end{tabular}

Note: ${ }^{*}$ - significant difference at $\mathrm{P}<0.05$.

A quantitative characteristic of the concentration of structural elements involved in the photosynthetic process is the specific surface density of leaves. We established that all antigibberellin drugs increased this figure by $14-16 \%$ due to changes in the mesostructure of the leaf (Kur'jata and Polyvanyj, 2015).

Processing plants using tebuconazole increased thickness of the main photosynthetic leaf tissue - chlorenchyma by 9\%. Under the action of Esfon and chlormequat chloride there was a nonsignificant thickening of the leaf plates. The thickness of the upper and lower epidermis of the leaf significantly increased under the influence of retardants. At the same time, for the actions of the all inhibitors of gibberellin there was a significant increase in the volume and size of cells of columnar cells spongy parenchyma. These changes in the mesostructure of the leaf plates of eggplant exposed to the actions retardants can create conditions for increasing the photosynthetic activity of cultures (Golunova and Kur'jata, 2012; Tkachuk, 2015).

An important indicator that affects the productivity of plants is the content of chlorophyll in the leaves. Our results show that during the growing season the growth inhibitory drugs increased the amount of chlorophyll $(\mathrm{a}+\mathrm{b})$. However, the indicator significantly increased only after application of the tebuconazole (Kur'jata and Polyvanyj, 2015).

Given the growth of leaf surface and wet weight of leaves per plant exposed to the actions of retardants, it is expedient to determine this important coenotic parameter as an index of chlorophyll. Our results indicate that Esfon, tebuconazole and chlormequat chloride increased it to $29 \%$, $26 \%$ and $24 \%$ respectively.

It is important in terms of efficiency of biological research on the productivity of plants to study the dynamics of dry matter accumulation of plants and net productivity of photosynthesis. We found that retardants increased plant dry weight compared with the control. However, the net photosynthetic productivity for the action of the tebuconazole and chlormequat chloride was virtually unchanged unlike Esfon (Golunova and Kur'jata, 2012; Kur'jata and Polyvanyj, 2015; Shevchuk and Kur'jata, 2015; Tkachuk, 2015).

Analysis of the data indicates a lower total content of carbohydrates (sugars + starch) in the leaves of the experimental plants in comparison with the control, which, in our opinion, points to more intensive outflow of assimilates to attraction centers - fruit. Despite the decline in sugar and starch per unit mass of the leaf in versions with both chlormequat chloride and tebuconazole, the total potential donor plants in these variants was higher due to increase in number, weight and leaf area. This led to increased productivity of the culture under the influence of drugs.

In the version with Esfon, which formed a lesser number of smaller fruits, outflow of carbohydrates was slowed, concentration remained higher compared to other retardants, and the content of the main reserve polysaccharide - starch was higher than in the control (Table 2).

Thus, slowing of the growth process and production of fewer fruits (basic acceptors of assimilates in the plant) under the influence of Esfon led to a slowdown of their outflow from the leaves. On the other hand, due to the formation of fewer leaves, their mass and the surface area of assimilating plants, formed less powerful potential donor plants. The consequence of these processes was a reduction in the productivity of the culture exposed to the action of ethylene producers.

We found that by processing plants with tebuconazole and chlormequat chloride the dry matter of fruit significantly higher than the control. The dynamics of laying and formation of the fruit on the plant were also positively influenced by the actions of the retardants. Their number in comparison with control increased by $15 \%$ and $6 \%$ respectively. Number of fruits per plant was decreased when 
Esfon was used. However, the average fruit weight was significantly increased only by the action of tebuconazole
(Golunova and Kur'jata, 2012; Kur'jata and Polyvanyj, 2015; Shevchuk and Kur'jata, 2015; Tkachuk, 2015).

The impact of antigibberellin drugs on the contents of different forms of carbohydrates in the leaves of eggplant of the cultivar Diamond during the fruiting phase (\% dry matter, average data for 2013-2015, $n=5$ )

\begin{tabular}{|l|c|c|c|}
\hline \multicolumn{1}{|c|}{ Indicator } & Total amount of sugar & Starch & Total amount of carbohydrate \\
\hline Control & $5.33 \pm 0.212$ & $2.62 \pm 0.092$ & $7.95 \pm 0.319$ \\
\hline 2-CEPA & $4.86 \pm 0.183$ & $2.81 \pm 0.111$ & $7.67 \pm 0.280$ \\
\hline EW-250 & $3.51 \pm 0.120^{*}$ & $2.29 \pm 0.088^{*}$ & $5.80 \pm 0.227^{*}$ \\
\hline CCC-750 & $4.43 \pm 0.154^{*}$ & $2.06 \pm 0.064^{*}$ & $6.48 \pm 0.243^{*}$ \\
\hline
\end{tabular}

Note: * - significant difference at $\mathrm{P}<0.05$.

These changes in the quantitative indicators of performance elements of eggplants exposed to the action of retardants stimulated the growth of harvest fruit from one plant to $11 \%$ after treatment with tebuconazole and $7 \%$ after the application of chlormequat chloride. Thus, the weakening rate of growth processes in plants of eggplant of Diamond sort by inhibition of the activity of apical meristem influenced by gibberellin synthesis inhibitors contributed to the laying of more fruit per plant, and redistribution of excess plastic substancesto the generative organs - the fruits. At the same time, inhibition of apical meristem influenced retardants led to increasing of compensation activity of marginal leaf meristem, leading to an increase of leaf area and leaf thickening plates. Growth of chlorophyll in plants treated with the triazole based drug tebuconazole led to increase in the index of the chlorophyll and in conjunction with other positive changes in morphometry was a prerequisite for a substantial increase in crop productivity.

\section{Conclusions}

Antigibberellin agents with different mechanisms of action prompted widespread changes in morphogenesis and performance of eggplants of the Diamond sort. Tebuconazole and chlormequat chloride increased linear dimensions of research plants and the plant dry substance weight of the whole plant. The retardants tebuconazole and chlormequat chloride significantly increased the number of leaves on plants and the dry substance weight of the leaves. Under the influence of these agents the leaf area, leaf index and specific leaf surface density increased. Processing of tebuconazole. All antigibberellin agents have stimulated chlorenchyma sprawl, increased volume and size of columnar cells and spongy parenchyma cells, increased chlorophyll content and chlorophyllic index of crops. Under the influence of retardants sugar content and starch in leaves were reduced because of enhanced outflow to the fruits, which the plants treated with drugs laid more. Use of triazole-based and onium retardants had a positive impact on formation of elements of culture productivity, which led to increase in fruit yield increase. Application of tebuconazole was the most effective.

\section{References}

Bala, M., Gupta, S., Gupta, N.K., Sangha, M.K., 2013. Practicals in plant physiology and biochemistry. Scientific, Jodhpur.

de Campos, M.F., Backes, C., Roters, J.M.C., Ono, E.O., Rodrigues, J.D., 2010. Influence of growth retardants on the development of Gladiolus communis L. plants. Biotemas 23(3), 31-36.

Golunova, L.A., 2015. Dija hlormekvathlorydu na produktyvnist' ta jakist' nasinnja Glycine $\max$ L. Naukovi Zapysky Terno- pil's'kogo Nacional'nogo Pedagogichnogo Universytetu. Serija Biologija 62, 68-72 (in Ukrainian).

Golunova, L.A., Kur'jata, V.G., 2012. Anatomo-morfologichni osoblyvosti roslyn soi' za kompleksnoi' dii' Bradyrhizobium japonicum i retardantiv. Naukovi Zapysky Ternopil's'kogo Nacional'nogo Pedagogichnogo Universytetu. Serija Biologija 52, 66-71 (in Ukrainian).

Guljajeva, G.B., Kur'jata, V.G., 2013. Fosforne zhyvlennja, fotosyntez i produktyvnist' cukrovogo burjaka za dii' biologichno aktyvnyh rechovyn [Phosphate nutrition, photosynthesis and productivity of sugar beet by the action of biologically active substances]. Interservis, Kyiv (in Ukrainian).

Kirizij, D.A., Stasyk, O.O., Prjadkyna, G.A., Shadchyna, T.M., 2014. Fotosintez: Assimiljacija $\mathrm{CO}_{2}$ i mehanizmy ee reguljacii [Photosynthesis: $\mathrm{CO}_{2}$ assimilation and the mechanisms of its regulation]. Logos, Kyiv (in Russian).

Kur'jata, V.G., Polyvanyj, S.V., 2015. Potuzhnist' fotosyntetychnogo aparatu ta nasinnjeva produktyvnist' maku olijnogo za dii' retardantu folikuru. Fyzyologyja Rastenyj i Genetyka 47(4), 313-320 (in Ukrainian).

Moreira, R.A., Moreira, R.C.A., Ramos, J.D., Silva, F.O.R., 2011. Regularidade da produção de tangerineiras ponkan submetidas ao raleio químico bianual. Revista Brasileira de Fruticultura 33, 235-240.

Nagashima, G.T., Santos, F.T., Miglioranza, E., 2011. Respostas de cultivares de algodão ao cloreto de mepiquat aplicado via embebição de sementes. Bragantia 70(1), 46-49.

Polyvanyj, S.V., Kur'jata, V.G., 2014. Vplyv sumishi treptolemu ta hlormekvathlorydu na produktyvnist' ta jakist' produkcii' maku olijnogo. Visnyk Lugans'kogo Nacional'nogo Universytetu Imeni Tarasa Shevchenka 8(1), 48-55 (in Ukrainian).

Poproc'ka, I.V., 2014. Zminy v polisaharydnomu kompleksi klitynnyh stinok sim'jadolej prorostkiv garbuza za riznoi' napruzhenosti donorno-akceptornyh vidnosyn v procesi prorostannja. Fyzyologyja Rastenyj i Genetyka 46(3), 190-195 (in Ukrainian).

Rogach, V.V., Rogach, T.I., 2015. Vplyv syntetychnyh stymuljatoriv rostu na morfofiziologichni harakterystyky ta biologichnu produktyvnist' kul'tury kartopli. Vìsn. Dnìpropetr. Unìv. Ser. Bìol. Ekol. 23(2), 221-224 (in Ukrainian).

Shevchuk, O.A., Kur'jata, V.G., 2015. Dija retardantiv na morfogenez, gazoobmin i produktyvnist' cukrovyh burjakiv [Effect of retardants on morphogenesis, interchange of gases and productivity of suger beet plants]. Nilan, Vinnycja (in Ukrainian).

Taran, N.J., Storozhenko, V.O., Bacmanova, L.M., Okanenko, O.A., Serga, O.I., Makarenko, V.I., 2014. Potuzhnist' rozvytku fotosyntetychnogo aparatu ta vrozhajnist' roslyn ozymoi' pshenyci za dii' benzylaminopurynu ta peroksydu vodnju. Fyzyologyja Rastenyj i Genetyka 46(5), 413-419 (in Ukrainian).

Tkachuk, O.O., 2015. Vplyv paklobutrazolu na anatomomorfologichni pokaznyky roslyn kartopli. Naukovyj Visnyk Shidnojevropejs'kogo Nacional'nogo Universytetu Imeni Lesi Ukrai'nky 2, 47-50 (in Ukrainian).

Van Emden, H.F., 2008. Statistics for terrified biologists. Blackwell, Oxford.

Надійшла до редколегї 24.03.2016 